4. Vallet B, Blanloeil Y, Cholley B, Orliaguet G, Pierre S, Tavernier B. Guidelines for perioperative haemodynamic optimization. Ann Fr Anesth Reanim. 2013;32:151-8.

doi: https://doi.org/10.1016/j.annfar.2013.09.010

5. Hoste K, Maitland CS, Brudney R, Mehta J-L, Vincent D, Yates JA, Kellum MG, Mythen AD, Shaw JG. Hardman. Four phases of intravenous fluid therapy: a conceptual model. BJA. 2014;113(5):740-7. doi: https://doi.org/10.1093/bja/aeu300

6. Intravenous fluid therapy in adults in hospital: clinical guideline CG174 (2017) London: National Institute for Health and Care Excellence. Available from: https://www.nice.org.uk/guidance/cg174

7. Kyle UG, Bosaeus I, De Lorenzo AD. Bioelectrical impedance analysis-part II: utilization in clinical practice. Clin Nutr. 2014;23(6):1430-53. doi: https://doi.org/10.1016/j.clnu.2004.09.012

8. Murray D. Improving outcomes following emergency laparotomy. Anaesthesia. 2014;69:300-5. doi: https://doi.org/10.1111/anae.12620

9. Corcoran T, Rhodes JE, Clarke S, et al. Perioperative fluid management strategies in major surgery: a stratified meta-analysis. Anesth Analg. 2012;114:640-51. doi: https://doi.org/10.1213/ANE.0b013e318240d6eb

10. Oliver CM, Walker E, Giannaris S, Grocott MPW, Moonesinghe SR. Risk assessment tools validated for patients undergoing emergency laparotomy: a systematic review British Journal of Anaesthesia. 2015;115(6):849-60. doi: https://doi.org/10.1093/bja/aev350

11. Iain Anderson et al. Update to the high-risk patient released by RCS England. NELA Project Team. Fourth Patient Report of the National Emergency Laparotomy Audit RcoA. Healthcare Quality Improvement Partnership as part of the National Clinical Audit Programme on behalf of NHS England and the Welsh Government, UK. Produced by the Publications Department Royal College of Anaesthetists, London. 2018;135. Available from: https://www.rcoa.ac.uk/news-and-bulletin/rcoa-news-and-statements/fourth-patient-nela-auditreport-published

12. Vivekanand KH, Mohankumar K. Clinical Outcome of Emergency Laparotomy: Our Experience at tertiary care centre (A case series). International Journal of Biomedical and Advance Research. 2015;6(10):709-14. doi: https://doi.org/10.7439/ijbar.v6i10.2578

Стаття надійшла до редакції 20.06.2019

\title{
О.Ю. Філіпnова
}

\section{МОЖЛИВОСТІ КОРЕКЦІї ЛІПІДНО-ФОСФОЛІПІДНИХ ПОРУШЕНЬ У ПАЦІЕНТІВ 3 НЕАЛКОГОЛЬНИМ СТЕАТОГЕПАТИТОМ НА ТЛІ ОЖИРІННЯ І ПАТОЛОГІЇ БІЛІАРНОГО ТРАКТУ}

ДЗ «Дніпропетровська медична академія МОЗ Украӥни» кафедра внутрішньої медииини 2

(зав. - д. мед. н., проф. О.В. Курята)

вул. В. Вернадського, 9, Дніпро, 49044, Украӥна

SE «Dnipropetrovsk medical academy of Health Ministry of Ukraine»

Department of Internal Medicine 2

V. Vernadsky str., 9, Dnipro, 49044, Ukraine

e-mail: Filippova-dma@i.ua

Цитування: Медичні перспективи. 2019. Т. 24, № 3. С. 45-52

Cited: Medicni perspektivi. 2019;24(3):45-52

Ключові слова: неалкогольний стеатогепатит, ожиріння, ліпіди, фосфоліпіди, урсодезоксихолієва кислота, аргініну глутамат

Ключевые слова: неалкогольный стеатогепатит, ожирение, липиды, фосфолипиды, урсодезоксихолиевая кислота, аргинина глутамат

Key words: nonalcoholic steatohepatitis, obesity, lipids, phospholipids, ursodeoxycholic acid, arginine glutamate 
Реферат. Возможности коррекции липидно-фосфолипидных нарушений у пациентов с неалкогольным стеатогепатитом на фоне ожирения и патологии билиарного тракта. Филиппова А.Ю. Большое значение в патогенезе и лечении неалкогольного стеатогепатита (НАСГ) уделяется нарушениям липидно-фосфолипидных фракций, которые имеют непосредственное отношение к процессам функционирования гепатоцитов. Цель исследования - оченить влияние различных схем комплексного лечения на показатели липиднофосфолипидных фракций у пациентов с НАСГ в сочетании с ожирением (ОЖ) и патологией билиарного тракта (БТ) по данным 6-месячного динамического наблюдения. Обследовано 52 пащиента с НАСГ в сочетании с ОЖ и патологией БТ. Контрольная группа состояла из 20 практически здоровых лиц. Исследовано влияние комплексного лечения (профилактических и лечебных мероприятий) на показатели липидно-фосфолипидных фракций у больных с НАСГ в сочетании с ожирением и патологией билиарного тракта. Выявлены изменения показателей липидного-фосфолипидных фракичй сыворотки крови до начала лечения во всех группах наблюдения, которые сопровождались снижением содержания фосфолипидов (ФЛ), фосфатидилхолина и сфингомиелина и значительнылм ростом лизоформ ФЛ-лизофосфатидилхолина и фосфатидилэтаноламина, триглищеридов, эфиров холестерола (от $p<0,05$ до $p<0,001)$. Комбинированная терапия с включением в стандартное лечение препаратов урсодезоксихолиевой кислоты и аргинина глутамата при коморбидном течении НАСГ может рассматриваться как перспективное направление в лечении этой категории пациентов, которое позволяет улучшить показатели липидно-фосфолипидных фракций и стабилизировать мембрану гепатоцитов (от $p<0,05$ до $p<0,001)$.

Abstract. Possibilities of correction of lipid-phospholipid disorders in patients with non-alcoholic steatohepatitis against obesity and pathology of the biliary tract. Filippova A.Yu. High priority in the pathogenesis and treatment of non-alcoholic steatohepatitis (NASH) is given to disorders of lipid-phospholipid fractions, which are directly related to the functioning of hepatocytes. The aim of the study was to evaluate the effect of various complex treatment regimens on lipid-phospholipid fractions in patients with NASH in combination with obesity (OB) and pathology of the biliary tract (BT) according to a 6-month follow-up. 52 patients with NASH in combination with OB and BT pathology were examined. The control group consisted of 20 practically healthy individuals. The effect of complex treatment (preventive and therapeutic measures) on the indicators of lipid-phospholipid fractions in patients with NASH in combination with obesity and pathology of the biliary tract was studied. Changes in the indicators of serum lipid-phospholipid fractions were detected before treatment in all observation groups, which were accompanied by decrease in phospholipids (PL), phosphatidylcholine and sphingomyelin content and a significant increase in PL lysoforms - lysophosphatidylcholine and phosphatidylethanolamine, triglycerides, cholesterol esters (from $p<0.05$ to $p<0.001$ ). Combination therapy with the inclusion in the standard treatment of ursodeoxycholic acid and arginine glutamate in the comorbid course of NASH can be considered as a promising direction in the treatment of this category of patients, this allows to improve indicators of lipid-phospholipid fractions and stabilize the hepatocytes' membrane (from $p<0.05$ to $p<0.001$ ).

Неалкогольна жирова хвороба печінки (НАЖХП) є хронічним, прогресуючим захворюванням, часом складно діагностується і сьогодні розглядається в рамках міждисциплінарних проблем медицини [6, 7]. Клінічна маніфестація цього захворювання відбувається на пізніх стадіях розвитку, що значно звужує спектр лікувальних заходів [6, 8]. НАЖХП та ожиріння (ОЖ) мають багато спільного: від факторів ризику, соціальних аспектів до патогенетичних механізмів, які включають енергетичний дисбаланс, генетичні та епігенетичні фактори, порушення метаболізму ліпідів, оксидативний стрес, запалення, дисбіоз [8, 9]. Велике значення в патогенезі неалкогольного стеатогепатиту (НАСГ), як прогресуючої форми НАЖХП, приділяється порушенням ліпідного обміну, особливо мебраностабілізуючій функції, що має безпосереднє відношення до процесів функціонування гепатоцитів і печінкової паренхіми [4]. При НАЖХП у першу чергу страждають мембрани гепатоцитів, вони раніше, ніж інші клітинні структури, зустрічаються 3 пошкоджуючими агентами й захи- щають внутрішню структуру клітини від зовнішніх впливів [5]. Сьогодні практично відсутні роботи, які висвітлюють зміни мембраностабілізуючої функції гепатоцитів та ліпідно-фосфоліпідні порушення, їх корекцію при прогресуванні НАЖХП. Порушення ліпідного обміну складні й різноманітні - внаслідок неоднорідності ліпідів [3, 10]. Саме ліпіди і фосфоліпіди відіграють важливу роль у клітинному метаболізмі. Відомості про зміну ліпідів сироватки крові у хворих 3 НАЖХП нечисленні, в основному вони стосуються вивчення окремих ліпідних показників, a не одночасного дослідження показників ліпідно-фосфоліпідного спектра та їх корекції.

Лікування НАЖХП не завжди достатньо ефективне, відсутні стандартні схеми лікування захворювання, зокрема в коморбідних пацієнтів на тлі ожиріння та патології біліарного тракту (БТ). Передбачається, що лікування кожного захворювання окремо сприятиме покращенню перебігу супутнього за рахунок впливу на спільні патогенетичні ланки та зниження навантаження на метаболічні процеси в цілому [7]. Основні 
підходи до лікування НАСГ повинні мати комплексний характер з першочерговим впливом на метаболічні процеси, енергетичний дисбаланс i мембранний потенціал гепатоцитів. Таким чином, основною метою терапії НАЖХП є профілактика прогресування хвороби, для чого необхідно контролювати масу тіла, дотримуватися дієтичних рекомендацій, вести активний спосіб життя, відмовитися від шкідливих звичок, контролювати рівень глюкози в крові, коригувати ліпідний профіль і кишковий мікробіоценоз; крім того, буде потрібно проведення адекватної терапії супутніх захворювань [6]. На думку багатьох дослідників, дієтичне, фізичне та медикаментозне лікування хворих на НАЖХП можна розподілити на два етапи: перший - це лікування стеатозу печінки, яке передбачає немедикаментозне поступове зменшення маси тіла пацієнта. Другий етап - це медикаментозне зменшення запальної реакції з боку печінки, нормалізація іï функціонального стану та корекція метаболічних розладів у пацієнтів з НАСГ [7]. При виборі тактики лікування НАСГ у коморбідного пацієнта необхідно брати до уваги саме ці послідовні етапи.

Сьогодні встановлено, що немедикаментозні засоби сприяють зменшенню прогресування НАЖХП, що знаходить відображення в зниженні індексу маси тіла (IMT) і сприяє відновленню багатьох лабораторних показників у коморбідних пацієнтів. Саме тому немедикаментозні профілактичні засоби сьогодні вважаються терапією першої лінії в лікуванні НАЖХП.

Щодо медикаментозної терапії НАЖХП, то тут можливо виділити головний підхід, який полягає в нормалізації структурних пошкоджень мембрани гепатоцитів і зменшенні ступеня пошкодження печінкової паренхіми [7, 11]. У теперішній час існує досить великий арсенал лікарських засобів, що дозволяють впливати на мембрану гепатоцитів і процеси метаболізму. Так, добре відомі і давно 3 успіхом застосовуються препарати урсодезоксихолієвої кислоти (УДХК), що показали свою ефективність в терапії НАЖХП [11]. УДХК забезпечує тривалу клініко-біохімічну відповідь у терапії НАЖХП у багатьох дослідженнях, відповідає критеріям ефективності й безпеки та володіє багатьма плейотропними ефектами, цитопротективною дією, без якої на сьогодні не має майбутнього жоден з гепатопротекторів [11]. Стосовно аргініну глутамату, саме цей активний компонент стабілізує порушення в ліпідному обміні, має гепатопротекторні властивості при коморбідному перебігу багатьох хронічних дифузних захворювань печінки [2].
Отже, складним питанням для клініциста залишається лікування хворого 3 коморбідною патологією, актуальним $є$ пошук нових засобів для комплексної терапії НАЖХП, чому було присвячено наше дослідження.

Мета дослідження - оцінити вплив різних схем комплексного лікування на показники ліпідно-фосфоліпідних фракцій у пацієнтів 3 НАСГ у поєднанні з ОЖ і патологією БТ за даними 6-місячного динамічного спостереження.

МАТЕРІАЛИ ТА МЕТОДИ ДОСЛІДЖЕНЬ

Обстежено 52 пацієнти 3 НАСГ у поєднанні 3 ОЖ і патологією БТ, які перебували на стаціонарному лікуванні в клініці ДУ «Інститут гастроентерології НАМН України», в яких під час сонографічного або морфологічного дослідження біоптату печінки були виявлені ознаки стеатозу печінки та стеатогепатиту. Серед хворих були 21 чоловік та 31 жінка. Середній вік пацієнтів $52,2 \pm 1,1$ року. Контрольна група складалася 320 практично здорових осіб (ПЗО), порівняних за віком (середній вік - 46,5 $\pm 2,3$ року) і статтю (9 чоловіків, 11 жінок) з пацієнтами основної групи $(\mathrm{p}>0,05)$.

Діагноз НАЖХП та патології БТ (хронічного безкам'яного холециститу, хронічного калькульозного холециститу, постхолецистектомічного синдрому) установлено відповідно до стандартизованих протоколів діагностики та лікування хвороб органів травлення, згідно 3 рекомендаціями МО3 України від 06.11.2014 № 826 «Про затвердження та впровадження медико-технологічних документів зі стандартизації медичної допомоги при хронічних неінфекційних гепатитах», а також практичними рекомендаціями Американської асоціації з вивчення захворювань печінки, Американської колегії гастроентерологів та Американської гастроентерологічної асоціації [7].

Хворі, залучені в дослідження, не зловживали алкоголем (споживання <50 г етанолу/тиждень для чоловіків, $<30$ г етанолу/тиждень для жінок протягом останнього року). В обстежених осіб не виявлено сироваткових маркерів вірусних гепатитів В і C, автоімунних та спадкових захворювань печінки.

3 метою виявлення надлишкової маси тіла та ОЖ всім пацієнтам проводили поглиблене антропометричне обстеження: натще зважували, вимірювали зріст хворого, визначали об'єм талії i об'єм стегон. ІМТ визначали за формулою Кетле.

Якісний склад і кількісний вміст ліпідів i фосфоліпідів (ФЛ) вивчали методом тонкошарової хроматографії (ТШХ), який дозволяє розділити їх на окремі компоненти [1]. Розділення 
ліпідних компонентів проводили після екстракції ліпідів за Фолчем і TШХ на пластинах Silufol, що дозволило виявити такі ліпідні компоненти: ФЛ, вільний холестерол (ВХС), неетерифіковані жирні кислоти (НЕЖК), ТГ, ефіри холестеролу (ЕХC). ФЛ розподілялися на такі фракції: лізофосфатидилхолін (ЛФТХ), фосфатидилхолін (ФТХ), сфінгомієлін (СФМ), фосфатидилетаноламін (ФТЕА).

Для оцінки ефективності різних схем лікування НАЖХП усі пацієнти були розподілені на 3 групи методом адаптивної рандомізації (розподіл пацієнтів на групи спочатку рівно ймовірно, потім - у групу з меншою чисельністю або рівно ймовірно). Усі виділені групи були статистично порівняними за віком i статтю пацієнтів, ступенем активності НАСГ, ступенем ожиріння за IMT, супутньою патологією БТ ( $>0,05$ при всіх порівняннях між групами). Хворим усіх груп, незалежно від схеми лікування, протягом 6-ти місяців було призначено корекцію способу життя, зокрема: режиму харчування, фізичних навантажень, праці та відпочинку.

Пацієнти 1 групи $(\mathrm{n}=16)$ отримували немедикаментозне лікування зі зменшенням калорійності раціону на 200 ккал кожні 2 тижні за рахунок обмеження простих вуглеводів та жирів тваринного походження та додавання до раціону сезонних свіжих овочів та фруктів. Аеробні фізичні навантаження - 150 хвилин та більше на тиждень 3 урахуванням фізичного стану і побажань пацієнтів. Медикаментозне лікування: стандартне лікування згідно 3 протоколами надання медичної допомоги при НАСГ та хронічних холециститах (метаболічні препарати 3 доведеною ефективністю L-карнітин, вітаміни групи В, міотропні спазмолітини - мебеверину гідрохлорид або прокінетики - домперидон) протягом 30 днів.

Пацієнти 2 групи (n=17) отримували немедикаментозне лікування зі зниженням калорійності раціону на 400 ккал кожні 2 тижні, за рахунок зменшення споживання простих вуглеводів та жирів тваринного походження 3 додаванням до раціону сезонних овочів та фруктів не менше 3-х порцій на день. Аеробні фізичні навантаження 200 хвилин та більше на тиждень. Медикаментозне лікування: стандартне лікування в поєднанні з УДХК протягом 30 днів у дозі 15 мг'кГ-1·д-1.

Пацієнти 3 групи (n=19) отримували немедикаментозне лікування зі зниженням калорійності раціону на 600 ккал кожні 2 тижні, яке досягається зниженням кількості спожитих вуглеводів та жирів 3 обов'язковим додаванням до раціону сезонних овочів та фруктів не менше 5ти порцій на день. Аеробні фізичні навантаження 250 та більше хвилин на тиждень. Медикаментозне лікування: стандартне лікування та УДХК поєднували 3 використанням аргініну глутамату (5 днів - довенно крапельно по 5 мл $40 \%$ розчину 3200 мл фізіологічного розчину двічі на добу, наступні 20 днів таблетки аргініну глутамату по 0,75 г тричі на добу).

Динамічне спостереження за ліпідно-фосфоліпідними фракціями сироватки крові було проведено в 52 хворих через 30 днів після лікування та в 30 хворих через 6 місяців після лікування.

Обробку первинних даних проводили за допомогою пакета програм Microsoft Office Excel2003 ${ }^{\circledR}$ (№ 74017-641-9475201-57075) (Microsoft Corporation, США) та ліцензійної програми STATISTICA v.6.1 (№ AGAR909E415822FA). 3 урахуванням закону розподілу (критерій Колмогорова-Смірнова 3 поправкою Лілієфорса), кількісні показники наведені у вигляді середнього значення та стандартної похибки середнього $(\mathrm{M} \pm \mathrm{m})$. Для порівняння середніх показників між групами і в динаміці використовували критерії Стьюдента (t) і Манна - Уїтні (U) для незв'язаних вибірок, для зв'язаних - критерії Стьюдента (T) і Вілкоксона (W) із застосуванням поправки Бонфероні при множинному порівнянні.

\section{РЕЗУЛЬТАТИ ТА ЇХ ОБГОВОРЕННЯ}

При аналізі показників фракцій ліпідів сироватки крові у хворих з коморбідним перебігом НАСГ до початку лікування було встановлено (табл. 1), що порушення фракційного складу ліпідів відбувалися в усіх групах хворих (від $\mathrm{p}<0,05$ до $\mathrm{p}<0,001)$. Найбільш суттєвими були зміни ФЛ зі значним зниженням у всіх групах спостереження по відношенню до ПЗО ( $<<0,001)$, поряд 3 підвищенням процентного вмісту ВХС, ТГ, ЕХС (від $\mathrm{p}<0,05$ до $\mathrm{p}<0,001$ ), що вказує на якісні зміни спектра нейтральних ліпідів у коморбідних хворих 3 прогресуючою стадією НАЖХП.

Проведення дослідження фракцій ліпідів сироватки крові в динаміці дозволило встановити (табл. 1), що на момент закінчення лікування на 30 день у 3 групі рівень ФЛ збільшувався в 1,6 раза та досягав нормальних значень через 6 місяців після лікування зі збільшенням в 1,9 раза відносно показників до лікування $(\mathrm{p}<0,001)$, у той же час у 1 групі зберігався знижений рівень ФЛ відносно пацієнтів 2 групи $(\mathrm{p}<0,05)$ та 3 групи $(\mathrm{p}<0,01)$. Повна нормалізація рівня $\mathrm{BXC}$ спостерігалася лише в 3 групі зі збільшенням в 1,5 раза через 6 місяців після лікування, що статистично відрізняло цих хворих від пацієнтів 
1 групи $(\mathrm{p}<0,05)$. Рівень НЕЖК у всіх групах спостереження статистично не відрізнявся від значень ПЗО. Статистично значущий напрямок змін ТГ відзначено вже через 30 днів після лікування зі зменшенням в 1,4 раза через 6 місяців у 2 групі та 3 групі відносно показників до лікування (від $\mathrm{p}<0,01$ до $\mathrm{p}<0,001$ ). Повна нормалізація ЕХC фіксувалася лише в 3 групі зі зниженням в 1,2 раза $(\mathrm{p}<0,001)$ через 6 місяців після лікування, що статистично відрізняло цих пацієнтів від 1 групи $(\mathrm{p}<0,05)$.

Табличяя 1

\section{Показники фракцій ліпідів сироватки крові у хворих на НАСГ із супутнім ОЖ і патологією БТ у динаміці лікування $(\mathrm{P} \pm \mathrm{m})$}

\begin{tabular}{|c|c|c|c|c|c|c|}
\hline Показник & $\begin{array}{l}\Pi 30, \\
\mathbf{n}=\mathbf{2 0}\end{array}$ & Група & До лікування & Через 30 днів & Група & Через 6 місяців \\
\hline \multirow[t]{3}{*}{$\overline{\Phi Л, ~ \% ~}$} & $\begin{array}{l}25,56 \\
\pm 0,82\end{array}$ & $1(n=16)$ & $15,45 \pm 1,75 \# \# \#$ & $17,75 \pm 1,38 \# \# \#$ & $1(n=10)$ & $18,04 \pm 1,63 \# \# \#$ \\
\hline & & $2(n=17)$ & $15,07 \pm 1,86 \# \# \#$ & $21,09 \pm 0,55 * * \# \# "$ & $2(n=9)$ & $23,24 \pm 1,53 * * \prime \prime$ \\
\hline & & $3(n=19)$ & $13,70 \pm 1,45 \# \# \#$ & 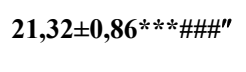 & $3(n=11)$ & $\begin{array}{c}25,40 \pm 1,53 * * * \\
\prime \prime \prime\end{array}$ \\
\hline \multirow[t]{3}{*}{ BXC, \% } & $\begin{array}{l}14,06 \\
\pm 0,26\end{array}$ & $1(n=16)$ & $20,76 \pm 1,35 \# \# \#$ & $18,38 \pm 1,22 \# \#$ & $1(n=10)$ & $17,25 \pm 1,02 * \#$ \\
\hline & & $2(n=17)$ & $22,45 \pm 1,60 \# \# \#$ & $16,54 \pm 0,99 * * \#$ & $2(n=9)$ & $15,52 \pm 1,17^{* *}$ \\
\hline & & $3(n=19)$ & $21,52 \pm 1,49 \# \# \#$ & $16,07 \pm 0,79 * * \#$ & $3(n=11)$ & $14,30 \pm 1,06 * * * \prime \prime$ \\
\hline \multirow[t]{3}{*}{ НЕЖК, \% } & $\begin{array}{c}8,42 \\
\pm 0,35\end{array}$ & $1(n=16)$ & $8,96 \pm 1,24$ & $8,70 \pm 0,79$ & $1(n=10)$ & $8,50 \pm 0,91$ \\
\hline & & $2(n=17)$ & $8,39 \pm 0,84$ & $8,15 \pm 0,29$ & $2(n=9)$ & $7,63 \pm 0,36$ \\
\hline & & $3(n=19)$ & $8,34 \pm 0,91$ & $8,04 \pm 0,30$ & $3(n=11)$ & $7,32 \pm 0,42$ \\
\hline \multirow[t]{3}{*}{ ТГ, \% } & $\begin{array}{l}16,11 \\
\pm 0,22\end{array}$ & $1(n=16)$ & $22,13 \pm 1,94 \# \#$ & $18,68 \pm 1,27 \#$ & $1(n=10)$ & $17,81 \pm 1,65$ \\
\hline & & $2(n=17)$ & $22,38 \pm 1,56 \# \# \#$ & $17,44 \pm 0,84 * *$ & $2(n=9)$ & $15,94 \pm 0,57 * * *$ \\
\hline & & $3(n=19)$ & $21,17 \pm 0,97 \# \# \#$ & $16,02 \pm 0,65 * * *$ & $3(n=11)$ & $15,21 \pm 0,87 * * *$ \\
\hline \multirow[t]{3}{*}{ EXC, $\%$} & $\begin{array}{l}32,72 \\
\pm 0,40\end{array}$ & $1(n=16)$ & $37,49 \pm 1,99 \#$ & $36,17 \pm 1,83 \#$ & $1(n=10)$ & $35,26 \pm 1,11 \#$ \\
\hline & & $2(n=17)$ & $39,65 \pm 1,91 \# \#$ & $35,22 \pm 1,08 * \#$ & $2(n=9)$ & $34,12 \pm 1,51^{*}$ \\
\hline & & $3(n=19)$ & $38,49 \pm 1,31 \# \# \#$ & $34,04 \pm 1,08 * *$ & $3(n=11)$ & $32,09 \pm 1,14 * * * \prime \prime$ \\
\hline
\end{tabular}

Примітки: * ${ }^{*}$ p $<0,05 ; * *-\mathrm{p}<0,01 ; * * *-\mathrm{p}<0,001$ порівняно з рівнем до лікування; \# - $<<0,05$; \#\# - p<0,01; \#\#\# - p<0,001 порівняно ПЗО; " - $<<0,05 ; "$;" $-\mathrm{p}<0,01$ порівняно 31 групою пацієнтів.

Результати вивчення фракцій фосфоліпідів у сироватці крові у хворих на НАСГ представлені в таблиці 2. У коморбідних пацієнтів з НАСГ у всіх групах спостереження достовірно підвищується вміст лізоформ фосфоліпідів у сироватці крові - ЛФТХ порівняно $з$ даними контрольної групи $(\mathrm{p}<0,001)$. Аналогічне підвищення по відношенню до контрольних значень спостерігалося і з боку таких фракції ФТЕА $(\mathrm{p}<0,001)$ на тлі зниження процентного вмісту СФМ, ФТХ у всіх групах (від $\mathrm{p}<0,05$ до $\mathrm{p}<0,001)$.

При аналізі даних фосфоліпідних фракцій сироватки крові після лікування (табл. 2) було встановлено, що нормалізація рівня ЛФТХ спостерігалася лише в пацієнтів 3 групи зі зниженням в 1,7 раза через 6 місяців після лікування $(\mathrm{p}<0,001)$, що також було вірогідним по відношенню до хворих 1 та 2 груп ( $<<0,001)$.

Підвищення рівня СФМ в 1,2 раза через 30 днів після лікування та його нормалізація зі збільшенням в 1,3 раза при подальшому аналізі була також досягнута лише у хворих 3 групи, що статистично відрізняло показники цих пацієнтів від аналогічних значень 1 групи ( $<<0,05$ при всіх порівняннях).

Аналогічна картина була характерна для значень ФТХ, які також збільшилися в 1,2 та 1,3 раза відповідно через 30 днів $(\mathrm{p}<0,05)$ та досягли нормальних показників через 6 місяців після лікування лише в пацієнтів 3 групи 
( $<<0,001)$, що статистично відрізняло цих хворих від 1 групи $(\mathrm{p}<0,05)$. При аналізі отриманих даних щодо показників ФТЕА вірогідні значення були отримані у хворих 2 i 3 груп $(\mathrm{p}<0,001)$.
Нормалізація ФТЕА зі збільшенням у 2,2 раза через 6 місяців після лікування щодо вихідних показників $(\mathrm{p}<0,001)$ та показників 1 групи $(\mathrm{p}<0,01)$ фіксувалася нами в 3 групі.

Таблиця 2

Показники фракцій фосфоліпідів сироватки крові у хворих на НАСГ
із супутнім ОЖ і патологією БТ у динаміці лікування (P \pm m)

\begin{tabular}{|c|c|c|c|c|c|c|}
\hline Показник & ПЗО, $\mathbf{n = 2 0}$ & Група & До лікування & Через 30 днів & Група & Через 6 місяців \\
\hline \multirow[t]{3}{*}{ ЛФТХ, \% } & $6,46 \pm 0,20$ & $1(n=16)$ & $10,76 \pm 1,04 \# \# \#$ & $9,23 \pm 0,80 \# \#$ & $1(n=10)$ & $8,61 \pm 0,82 \#$ \\
\hline & & $2(n=17)$ & $10,01 \pm 0,68 \# \# \#$ & $7,95 \pm 0,58 * \#$ & $2(n=9)$ & $7,20 \pm 0,13 * * * \#$ \\
\hline & & $3(n=19)$ & $10,34 \pm 0,90 \# \# \#$ & $\begin{array}{c}7, \mathbf{4 4} \pm 0,42 \\
* * \# "\end{array}$ & $3(n=11)$ & $5,94 \pm 0,29 * * * \cdots " \square$ \\
\hline \multirow[t]{3}{*}{ СФМ, \% } & $17,46 \pm 0,32$ & $1(n=16)$ & $12,88 \pm 1,25 \# \#$ & $13,70 \pm 0,99 \# \#$ & $1(n=10)$ & $14,68 \pm 0,93 \#$ \\
\hline & & $2(n=17)$ & $14,66 \pm 1,08 \#$ & $15,56 \pm 0,78 \#$ & $2(n=9)$ & $15,99 \pm 0,87$ \\
\hline & & $3(n=19)$ & $13,49 \pm 1,30 \# \#$ & $16,12 \pm 0,61$ *" & $3(n=11)$ & $17,49 \pm 1,06 * "$ \\
\hline \multirow[t]{3}{*}{ ФТХ, \% } & $65,5 \pm 0,56$ & $1(n=16)$ & $54,9 \pm 1,12 \# \# \#$ & $55,2 \pm 1,39 \# \# \#$ & $1(n=10)$ & $56,7 \pm 2,89 \#$ \\
\hline & & $2(n=17)$ & $52,2 \pm 1,61 \# \# \#$ & $56,1 \pm 2,72 \# \#$ & $2(n=9)$ & $61,0 \pm 3,80^{*}$ \\
\hline & & $3(n=19)$ & $52,4 \pm 1,75 \# \# \#$ & $60,4 \pm 2,70 *$ & $3(n=11)$ & $65,3 \pm 3,13 * * * "$ \\
\hline \multirow[t]{3}{*}{ ФТЕА, \% } & $10,46 \pm 0,33$ & $1(n=16)$ & $22,7 \pm 1,97 \# \# \#$ & $19,1 \pm 1,46 \# \# \#$ & $1(n=10)$ & $18,3 \pm 1,79 \# \#$ \\
\hline & & $2(n=17)$ & $24,5 \pm 2,52 \# \# \#$ & $14,3 \pm 1,27 * * * \# "$ & $2(n=9)$ & $12,0 \pm 1,43 * * * \prime$ \\
\hline & & $3(n=19)$ & $23,1 \pm 1,67 \# \# \#$ & $13,7 \pm 0,89 * * * \# \#^{\prime \prime \prime \prime}$ & $3(n=11)$ & $10,5 \pm 0,57 * * * \prime \prime \prime \prime$ \\
\hline
\end{tabular}

Примітки: * - $<<0,05 ; * *-p<0,01 ; * * *-p<0,001$ порівняно 3 рівнем до лікування; \# - p<0,05; \#\# - p<0,01; \#\#\# - p<0,001 порівняно 3 ПЗО; " - p<0,05; "'" - p<0,01 порівняно з 1 групою пацієнтів; - - p<0,01 порівняно з 2 групою пацієнтів.

На підставі результатів проведених досліджень було зроблено висновок, що коморбідний перебіг НАСГ супроводжується порушеннями в структурно-функціональному стані мембран гепатоцитів за рахунок дисбалансу ліпіднофосфоліпідних взаємодій. Їх основу становлять зміни ліпідного матриксу мембрани, що також може знаходити своє відображення у фізикохімічних властивостях мембранних білків [3]. Таким чином, будова і функція мембран гепатоцитів знаходяться в прямій залежності від рівня ліпідів і фосфоліпідів, що також знайшло відображення в роботах інших дослідників $[3,4,5]$, тому вивчення ліпідно-фосфоліпідного балансу представляє як науковий, так i практичний інтерес. Високий рівень ЛФТХ и ФТЕА при значному зниженні ФЛ може бути діагностичним критерієм порушення проникності мембран гепатоцитів у хворих на НАСГ у поєднанні з ОЖ і патологією БТ.

Проведення динамічного спостереження протягом 6-ти місяців дозволило встановити, що найбільш ефективним 3 вивчених варіантів диференційованого лікування $\epsilon$ приєднання УДХК й аргініну глутамату до стандартної терапії у хворих 3 групи, що забезпечує відновлення ліпідно-фосфоліпідних фракцій 3 подальшим усуненням дисбалансу в системі ліпіднофосфоліпідних взаємодій за рівнем ФТЕА, ФТХ, СФМ, а також вірогідним зменшенням процентного вмісту ЛФТХ $(\mathrm{p}<0,01)$ по відношенню до хворих 2 групи, які отримували лише препарати УДХК та тлі стандартного лікування. Крім того, слід відзначити відсутність побічних ефектів комплексної терапії протягом усього періоду лікування. Приєднання лише препаратів УДХК до стандартного лікування у хворих 2 групи також сприяло відновленню ліпідно-фосфоліпідних фракцій порівняно 3 хворими 1 групи (від $\mathrm{p}<0,05$ до $\mathrm{p}<0,01)$. Менш ефективним було проведення стандартної терапії, оскільки позитивні зміни ліпідно-фосфоліпідних показників були недостатньо вираженими і вірогідними тільки по відношенню до ПЗО та лабораторних даних до 
лікування (від $\mathrm{p}<0,05$ до $\mathrm{p}<0,001$ ). У цих пацієнтів зберігався стан помірного загострення хронічної патології гепатобіліарної системи.

Таким чином, вивчення закономірностей механізмів гальмування мембранодеструктивних процесів дозволяє розширювати можливості лікувальних заходів на основі введення замісних препаратів, які відновлюють структуру клітинних мембран гепатоцитів у пацієнтів з НАСГ на тлі ОЖ і патології БТ.

\section{ВИСНОВКИ}

1. У хворих на НАСГ поєднаний перебіг захворювання супроводжується змінами показників фракцій ліпідів сироватки крові зі значним зниженням у всіх групах спостереження ФЛ по відношенню до ПЗО ( $<0,001)$, поряд 3 підвищенням процентного вмісту ВХС, ТГ, ЕХС (від $\mathrm{p}<0,05$ до $\mathrm{p}<0,001)$, що сприяє підтримці структурних змін у мембрані гепатоцитів та в гепатобіліарній системі.

2. У коморбідних пацієнтів з НАСГ встановлено збільшений вміст лізоформ фосфоліпідів у сироватці крові - ЛФТХ та ФТЕА на тлі зни- ження процентного вмісту СФМ, ФТХ у всіх групах (від $\mathrm{p}<0,05$ до $\mathrm{p}<0,001$ ), що може бути діагностичним критерієм порушення проникності мембран гепатоцитів.

3. Комплексна терапія хворих з коморбідним перебігом НАСГ дозволяє суттєво покращити показники ліпідно-фосфоліпідних фракцій, що може сприяти відновленню мембран гепатоцитів i зниженню ризику прогресування захворювання. Отримані результати дослідження свідчать, що комбінована терапія 3 включенням до стандартного лікування УДХК та аргініну глутамату при коморбідному перебігу НАСГ може розглядатися як перспективний напрямок у лікуванні цієї категорії пацієнтів, який дозволяє досягти відновлення основних показників ліпіднофосфоліпідних фракцій (від $\mathrm{p}<0,05$ до $\mathrm{p}<0,001$ ).

Перспективи подальших досліджень полягають у вивченні показників ендогенної інтоксикації в динаміці лікування у хворих 3 коморбідним перебігом НАСГ.

\section{СПИСОК ЛІТЕРАТУРИ}

1. Веселова Т. А., Веселов А. П., Дерюгина А. В. Тонкослойная хроматография липидов: учебно-метод. пособие. Н. Новгород: ННГУ, 2015. 23 с.

2. Клинико-фармакологические аспекты применения антиоксидантных лекарственных средств / Горошко О. А. и др. Международный журнал прикладных и фундаментальных исследований. 2016. № 4-5. C. 905-912.

3. Крыжановский С. П., Богданович Л. Н., Кушнерова Н. Ф., Шевченко Н. М. Фосфолипиды и нейтральные липиды крови у пациентов с дислипидемией и их коррекция полисахаридами из морских бурых водорослей. Фундаментальные исследования. 2014. № 10. С. 1951-1958.

4. Філіппова О. Ю. Дослідження взаємозв'язків між біліарною патологією та ліпіднофосфоліпідними змінами у хворих з неалкогольною жировою хворобою печінки та ожирінням. Science Rise Medical Science. 2016. T. 3, № 7. C. 55-60. DOI: https://doi.org/10.15587/2519-4798.2016.74545

5. Філіппова О.Ю. Ліпідно-фосфоліпідні порушення у пацієнтів 3 коморбідним перебігом неалкогольної жирової хвороби печінки та ожирінням на тлі патології біліарного тракту залежно від маси тіла. Світ медицини та біології. 2016. Т. 57, № 3. С. 85-90.

6. Ahmed A., Wong R. J., Harrison S. A. Nonalcoholic Fatty Liver Disease Review: Diagnosis, Treatment, and Outcomes. Clin Gastroenterol
Hepatol. 2015. Vol. 13, No. 12. P. 2062-2070. DOI: https://doi.org/10.1016/j.cgh.2015.07.029

7. An interpretation of the AASLD practice guideline on the diagnosis and management of nonalcoholic fatty liver disease in 2017 / Y. M. Nan et al. Zhonghua Gan. Zang. Bing. Za. Zhi. 2017. Vol. 25, No. 9. P. 687-694. DOI: https://doi.org/10.3760/cma.j.issn.10073418.2017.09.008

8. Della Corte C., Mazzotta A. R., Nobili V. Fatty liver disease and obesity in youth. Curr Opin Endocrinol Diabetes Obes. 2016. Vol. 23, No. 1. P. 66-71. DOI: https://doi.org/10.1097/MED.0000000000000221

9. Filippova A. Non-alcoholic and alcoholic fatty liver disease in patients suffering from biliary tract pathology and obesity: clinical and functional aspects. Modern Science-Moderni věda. 2015. No. 4. P. 134-149.

10. Grechanyk M., Grechanyk N., Kuryata A. Lipid metabolism, endothelial function, parameters of elastic properties and inflammation in patients with coronary heart disease combined with hepatic steatosis depending from body mass index. Atherosclerosis. 2018. Vol. 275. P. 148 DOI: https://doi.org/10.1016/j.atherosclerosis.2018.06.438/

11. Steinacher D., Claudel T., Trauner M. Therapeutic Mechanisms of Bile Acids and NorUrsodeoxycholic Acid in Non-Alcoholic Fatty Liver Disease. Dig. Dis. 2017. Vol. 35, No. 3. P. 2822-2887. DOI: doi: https://doi.org/10.1159/000454853 


\section{REFERENCES}

1. Veselova TA, Veselov AP, Deryugina AV. [Thin layer chromatography of lipids]. Uchebno-metodicheskoye posobiye. N. Novgorod: NNGU. 2015;23. Russian.

2. Goroshko OA, Kukes VG, Prokofiev AB, Arkhipov VV, Emchenkova YuE. [Clinical and pharmacological aspects of the use of antioxidant drugs]. International Journal of Applied and Fundamental Research. 2016;4-5:905-912. Russian.

3. Kryzhanovsky SP, Bogdanovich LN, Kushnerova NF, Shevchenko NM. [Phospholipids and neutral blood lipids in patients with dyslipidemia and their correction with polysaccharides from marine brown algae]. Fundamentalnye issledovaniya. 2014;10:1951-8. Russian.

4. Filippova OYu. [The relationship between biliary pathology and lipid-phospholipid changes in patients with nonalcoholic fatty liver disease and obesity]. Science Rise Medical Science. 2016;7(3):55-60. Ukrainian. doi: https://doi.org/10.15587/2519-4798.2016.74545

5. Filippova OYu. [Lipid-phospholipid disorders in patients with comorbid over nonalcoholic fatty liver disease and obesity on the background of pathology biliary tract depending on body weight]. Svit medytsyny ta biolohii. 2016;3(57):85-90. Ukrainian.

6. Ahmed A, Wong RJ, Harrison SA. Nonalcoholic Fatty Liver Disease Review: Diagnosis, Treatment, and Outcomes. Clin Gastroenterol Hepatol. 2015;13(12):206270. doi: https://doi.org/10.1016/j.cgh.2015.07.029
7. Nan YM, Fu N, Li WC, Kong LL, et.al. An interpretation of the AASLD practice guideline on the diagnosis and management of nonalcoholic fatty liver disease in 2017. Zhonghua Gan. Zang. Bing. Za. Zhi. 2017;25(9):687-94. doi: https://doi.org/10.3760/cma.j.issn.10073418.2017.09.008

8. Della Corte C, Mazzotta AR, Nobili V. Fatty liver disease and obesity in youth. Curr Opin Endocrinol Diabetes Obes. 2016;23(1):66-71. doi: https://doi.org/10.1097/MED.0000000000000221

9. Filippova A. Non-alcoholic and alcoholic fatty liver disease in patients suffering from biliary tract pathology and obesity: clinical and functional aspects. Modern Science - Moderni vĕda. 2015;4:134-49.

10. Grechanyk M, Grechanyk N, Kuryata A. Lipid metabolism, endothelial function, parameters of elastic properties and inflammation in patients with coronary heart disease combined with hepatic steatosis depending from body mass index. Atherosclerosis. 2018;275:148.

doi: https://doi.org/10.1016/j.atherosclerosis.2018.06.438/

11. Steinacher D, Claudel T, Trauner M. Therapeutic Mechanisms of Bile Acids and Nor-Ursodeoxycholic Acid in Non-Alcoholic Fatty Liver Disease. Dig. Dis. 2017;35(3):2822-87.

doi: https://doi.org/10.1159/000454853

Стаття надійшла до редакції 27.06.2019 